WwW.iibpas.com

\title{
RESEARCH STUDY ON BIO-DEGRADATION OF ANTIBIOTICS BY HERBAL AND MINERAL DRUGS -ITT METHOD
}

\author{
ANITHA H ${ }^{*}$, PANDYA MR $^{2}$, TOSHIKHANE $\mathbf{H}^{3}$ AND MATHAD $\mathrm{P}^{4}$ \\ 1: PhD Scholar, Dept. of RSBK, Parul Institute of Ayurved, Parul University
}

2: Professor \& Guide, Dept. of RSBK Parul Institute of Ayurved, Parul University

3: Dean, Faculty of Ayurved, Parul University

4: Professor, Dept. of RSBK Parul Institute of Ayurved and Research, Parul University

*Corresponding Author: Dr Anitha.H: E Mail: anitha.h86169@paruluniversity.ac.in

Received 12 ${ }^{\text {th }}$ Dec. 2021; Revised 14 ${ }^{\text {th }}$ Jan. 2022; Accepted $7^{\text {th }}$ Feb. 2022; Available online $5^{\text {th }}$ March 2022

\section{https://doi.org/10.31032/IJBPAS/2022/11.3.1072}

\begin{abstract}
ABSRRACT
Hospital effluents represent an important source for the release of Antibiotics into the environment. In present day increased concentration of Antibiotics in natural resources like soil, water has become major concern. Antibiotics are the one of the most important medicines used in hospitals and large amount of Antibiotics is released through hospital waste water due to excretion of used antibiotic and disposal of unused compounds. It leads to development of Multi Drug Resistance (MDR) in infants and resistant strains of bacteria which is emerging as serious health issue. Little is known about Bio-Degradation of Antibiotics in aquatic media and is important step in reducing concentration of Antibiotics.

In this context primary study was conducted by selected Herbal and Mineral drugs of Ayurveda against Ciprofloxacin by using Sohel's Reagent Method to access its molecular concentration in laboratory. Few Ayurveda drugs are proved to be efficient in degrading the selected Antibiotic.
\end{abstract}

Keywords: Antibiotic, Bio- Degradation, Ciprofloxacin, Sohel's Reagent Test

\section{INTRODUCTION}

The increased load of Antibiotic condition which may pose potential health concentration in environment especially in aquatic media has become alarming risks. Hospital effluents are the important source which are directly disposed to the 
open atmosphere or near water sources without treating to reduce concentration of Antibiotics in sewage water of hospital effectively. Hence it is essential to find a suitable measure to bio- degrade the Antibiotics.

1 in 10 people lack access to safe water worldwide, and about half the U.S. population lives without access to safe water. As the human population continues to grow access to safe water is of utmost importance. Water is needed not only for human consumption but also for livestock and agricultural use. Regions experiencing water scarcity turn to using water treatment facility to reuse wastewater for agricultural or even human use. Water treatment is not a well-researched process, but recent studies show that many treatment processes allow reintroduction of antibiotics, antibiotic resistance genes and resistant organisms back into the environment.Ciprofloxacin is included alongside amoxicillin, erythromycin, azithromycin and clarithromycin on the Watch List monitoring programme under the EU's Water Framework Directive, which gathers data on substances that may pose a risk at EU level.

Few Herbo Mineral drugs are selected viz Tankan (Borax), Sphatika (Potash Alum) of mineral origin Kapardika Bhasma (calyx of Cowiries) is marine origin Apamarga Kshara (Alkaline extract of Acarathus aspera) and Tulasi (Osimum sanctum) which are herbal in origin. In the present study these test drug samples are tested for their efficacy to bio- degrade Ciprofloxacin which is commonly practiced medication by adopting laboratory method.

\section{METHODOLOGY}

\section{Materials and Methods}

The study design includes qualitative Analysis by using Schole's Reagent Test with selected testing drug samples.

\section{Preparation of Sample Solution}

Preparation of Ciprofloxacin Solution: As per molecular concentration in terms of $\mathrm{w} / \mathrm{w} 1 \mathrm{gm}$ of Ciprofloxacin is dissolved in 10 parts of distilled water and suspension is prepared and kept for 6 hours before it is used for analysis.

\section{Preparation of Testing Drug Samples}

Tankana (Borax): According to molecular concentration in terms of $\mathrm{w} / \mathrm{w} 1 \mathrm{gm}$ of Tankana is dissolved in 13 parts of distilled water and solution is prepared and kept for 12 hours before it is used for analysis.

Sphatika (Potash Alum): According to molecular concentration in terms of $\mathrm{w} / \mathrm{w}$ $1 \mathrm{gm}$ of Sphatika is dissolved in 6 parts of distilled water and solution is prepared and kept for 12 hours before it is used for analysis.

Kapardika Bhasma (Calyx of Cowries): 
According to molecular concentration in terms

of w/w 1gm of Kapardika Bhasma is dissolved in 6 parts of distilled water and suspension is prepared is and kept for 12 hours before it is used for analysis.

Tulasi Swarasa (Osimum Sanctum): Fresh juice of Tulasi Filtrate is taken for analysis.

Apamarga Kshara (Alkaline extract of Achyranthes Aspera): According to molecular concentration in terms of $\mathrm{w} / \mathrm{w} 1 \mathrm{gm}$ of Apamarga Kshara is dissolved in 8 parts of distilled water and solution is prepared is prepared and kept for 12 hours before it is used for analysis.

\section{SITE OF THE STUDY:}

This Qualitative Study was conducted at Central Research Laboratory, PIAR.

\section{TYPE OF STUDY:}

Incubated Test Tube Method (ITT).

\section{PROCEDURE:}

The procedure is done by adopting Schole's Reagent Test Method. Qualitative assessment of molecular concentration of antibiotics is observed. The antibiotic degradation in terms of non-biotic form of selected drug (Ciprofloxacin) to inhibit or to reduce its effective functioning and make it chemically inert molecule. With this regard a qualitative test is carried out as according to pharmacopeial standards. It is mainly carried on the basis of molecular concentration with reference to antibiotic functioning versus non-biotic functioning.

\section{PREPARATION OF REAGENT:}

The reagent is prepared by using potassium cyanide and sodium carbonate solution which are used as marker component.

$1 \mathrm{ml}$ of sample solution is taken in test tube and $1 \mathrm{ml}$ of different testing drug solutions viz Tulasi Swarasa, Solution of Apamarga Kshara, Tankana Kshara, Sphatika, suspension of Kapardika Bhasma are added separately. Then scholes reagent drop by drop is added for the maximum concentration of $1 \mathrm{ml}$ and observations are recorded.

(The expected reaction that is transparency/turbidity of mixture after adding scholes reagent is noted)

\section{OBSERVATION}

It has been observed that among the testing drug samples, Tulasi Swarasa, Apamarga Kshara turns mixture to transparent. Hence can be stated that these test drugs are effective in reducing molecular concentration of Ciprofloxacin in said conditions in laboratory.

Tankana Kshara solution showed slightly turbid reaction and Sphatika, Kapardika Bhasma suspension was observed to be moderately turbid in appearance. 
Table 1: Shows Observations of testing drug samples against Ciprofloxacin

\begin{tabular}{|c|c|c|}
\hline S. No. & Names of Test Sample & Observation of Test \\
\hline $\mathbf{1}$ & Tulasi Swarasa & Transparent \\
\hline $\mathbf{2}$ & Solution of Apamarga Kshara & Transparent \\
\hline $\mathbf{3}$ & Solution of Tankana & Slightly Turbid \\
\hline $\mathbf{4}$ & Solution of Sphatika & Moderately Turbid \\
\hline $\mathbf{5}$ & Suspension of Kapardika Bhasma & Moderately Turbid \\
\hline
\end{tabular}

\section{DISCUSSION}

the development and spread of antimicrobial resistance (AMR) (the phenomenon of bacteria resisting the effects of antibiotics) can be constrained if measures are taken to improve the effectiveness of wastewater treatment processes and to control the use of antibiotics in medicine and animal husbandry

In the present study only direct concentration of known Antibiotic is taken to access the effective suppression of molecular strength of selected antibiotic in a qualitative method. The sample is not collected from any Sewage or hospital waste water. As the different concentration, form and molecular strength of different antibiotics may present in Sewage water, this study performed forms as baseline preparation for pilot study to conduct degradation of Antibiotic concentration in hospital Sewage water by using Herbal/ Mineral / marine sources.

Atter addition of scholes reagent drop by drop in the mixture of sample and test sample solution, it is observed for change in its appearance. If solution becomes transparent it indicates test sample is effective in reducing molecular concentration of Ciprofloxacin. On the contrary if the solution remains turbid, it indicates that test sample has got no action on ciprofloxacin.

\section{CONCLUSION}

Tulasi Swarasa, Apamarga Kshara and Tankana Kshara may be used for molecular degradation of selected antibiotic(Ciprofloxacin) as per the primary findings of ITT method as an initial step to resolve the problem of concern. These findings ate to be further studied for assessing its efficacy by subjecting to HPLC-SEM Method and Culture Method.

\section{Further Scope}

The study on degradation of Antibiotic by its Quantitative Estimation by adopting advanced Analytical techniques as HPLCSEM Method.

The study can be done on degradation of Antibiotic by Sampling Method.

Degradation of Antibiotic can be further assessed by Culture Method. 


\section{REFERENCES}

[1] Assessment of anaerobic bacterial diversity and its effects on anaerobic system stability and the occurrence of antibiotic resistance genes. Bioresour Technol 2016, 207:332-338.

[2] Al-Jassim N, Ansari MI, Harb M, Hong PY: Removal of bacterial contaminants and antibiotic resistance genes by conventional wastewater treatment processes in Saudi Arabia: Is the treated wastewater safe to reuse for agricultural irrigation? Water Res 2015, 73:277290.

[3] Jutkina J, Rutgersson C, Flach CF, Joakim Larsson DG: An assay for determining minimal concentrations of antibiotics that drive horizontal transfer of resistance. Sci Total Environ 2016, 548-549:131-138.
[4] ] Shaw JL, Monis P, Weyrich LS, Sawade E, Drikas M, Cooper AJ: Using Amplicon Sequencing To Characterize and Monitor Bacterial Diversity in Drinking Water Distribution Systems. Appl Environ Microbiol 2015, 81(18):6463-6473.

[5] Aminov, R. I., N. Garrigues-Jeanjean, and R. I. Mackie. 2001. Molecular ecology of tetracycline resistance: development and validation of primers for detection of tetracycline resistance genes encoding ribosomal protection proteins. Appl. Environ. Microbiol.67: $22-32$ 